\title{
Tribocorrosion behavior of new martensitic stainless steels in sodium chloride solution
}

\author{
A. Dalmau ${ }^{1,2}$, W. Rmili ${ }^{1}$, C. Richard ${ }^{1}$, A. Igual - Muñoz $^{2^{*}}$ \\ 1 Laboratoire de Mécanique et Rhéologie, Polytech Tours, 7 Avenue Marcel \\ Dassault, 37200 - Tours, France \\ 2 Institute for Industrial, Radiophysical and Environmental Safety, Universitat \\ Politècnica de València, Camino de Vera s/n, 46022 - Valencia, Spain \\ *Corresponding author: anigmu@iqn.upv.es
}

\begin{abstract}
The tribo-electrochemical behavior of two new martensitic stainless steels in a $3 \% \mathrm{NaCl}$ solution has been investigated. Different electrochemical and surface analysis techniques (Scanning Electron Microscopy, Focused Ion Beam) were discussed to analyse the influence of the effect of the electrochemical conditions on friction and wear, and to elucidate involved wear mechanisms (plastic deformation, plastic shakedown and low-cycle fatigue). The selected stainless steels degrade through a delamination type of wear mechanism. The effects of the applied potential on wear are related to the formation of a passive film which alters the mechanical behavior of the surface and subsurface of the materials to promote wear. A coefficient of friction below 0.6 promotes nanowear, and a transition was observed when the coefficient of friction exceeded that value.
\end{abstract}

Keywords: Martensitic stainless steels, tribocorrosion, wear, FIB 


\section{Introduction}

Aerospace structures differ from other structures due to the highest demands for performance and lightweight. Modern aerospace structures typically require the use of composite materials and advanced multifunctional materials. To obtain the level of performance required from flight structures, thorough knowledge of material limitations, structural stability and strength considerations are needed. In order to assure long aeronautical parts (i.e. rolling bearings) life and reliability for commercial, industrial and aerospace applications, materials, lubricants and design variables must be carefully considered and specified. The ability of the material to cope with each step in the sequence of manufacturing processes is seminal to its success or failure. Of the very many alloys that have been investigated for bearing steels, there are only two categories of steels which find application in the majority of bearings: those which are hardened throughout their sections into a martensitic or bainitic condition, and others which have soft cores but tenacious surface layers introduced using processes such as case or induction hardening [1]. Those are the reason why martensitic stainless steels are commonly used for manufacturing components when high mechanical properties and moderate corrosion resistance are needed [2].

On the other hand, the corrosion behaviour of stainless steels depends on the formation of an oxide film mainly composed of $\mathrm{Fe}, \mathrm{Cr}$ and $\mathrm{Ni}$ oxides, which spontaneously covers the surface of the alloy in presence of oxygen and/or water [3]. In many applications, such as bearings or gears, martensitic stainless steels may be subject to tribological conditions leading to wear [4][5]. When a contact operates in a corrosive environment its deterioration can be significantly affected by the surface chemical phenomena [6][7]. Under sliding or erosive conditions the passive film can be removed by abrasion thus exposing the bulk material to more severe corrosion (i.e. wear accelerated corrosion) [3][8], thus leading to a tribocorrosion degradation mechanism. Tribocorrosion is defined as a form of solid surface alteration that involves the joint action of relatively moving mechanical contact with chemical or electrochemical reaction in which the result may be different in effect than both processes acting separately [9]. Tribocorrosion involves different degradation phenomena (corrosion, wear accelerated corrosion and wear) depending on duty cycle (locomotion, rest phase) and location (bearing area, structural parts) [10]. Corrosion occurs on the whole metal surface exposed to the corrosive fluids while 
wear accelerated corrosion and mechanical wear occur only on the area subjected to sliding and the contact area respectively. Knowledge of the mechanisms involved in the simultaneous action of wear and corrosion leads to the development of new tools and components, which enable forecasting the wear in sliding pairs of machines under regular working conditions [11]. In case of aeronautical parts, such as bearings and gears, because of their functionality, understanding tribocorrosion mechanisms is relevant to prevent the early failure of the bearings.

New martensitic stainless steels possessing specific properties to suit particular applications have been developed nowadays. The aim of this development is to provide high mechanical properties by simple surface treatments and improve their corrosion resistance. Previous studies show that this type of martensitic steels shows similar corrosion behavior as the reference austenitic one, AISI 316L [12]. Combined studies of the corrosion-fatigue behavior of martensitic stainless steels have been carried out and different mechanisms of crack initiation have been suggested [13]. However, the tribocorrosion behavior of martensitic staintess steels has been scarcely explored. Stachowiak and Zwierycki [11] studied the tribocorrosion behavior of the AISI 420 martensitic stainless steel, in comparaison with an austenitic and ferritic one, in a sliding pair of pin-on-plate tribometer in sulfuric acid, concluding that the tribocorrosion and wear behavior depend on the original properties of steel (resistance to abrasion and corrosion). Few studies have been focused on analyzing the tribocorrosion behavior of martensitic stainless steels with surface treatment, such as plasma nitriding [14] and cromizing coating [15]. From those results, it was observed that both surface treatments enhanced surface hardness and wear resistance.

The aim of this study is to characterize the tribocorrosion behavior and wear mechanisms of new martensitic stainless steels in a $3 \% \mathrm{NaCl}$ solution and compare them with an austenitic one (AISI 316L), used as a reference. It also aims to study the effect of the electrochemical conditions on friction and wear. 


\section{Experimental}

\subsection{Materials and sample preparation}

Two different martensitic stainless steels, one precipitation hardening type with double structural hardening, X1CrNiMoAITi12-11-2, and one carburizing martensitic stainless steels, $\mathrm{X} 12 \mathrm{CrNiMoV12}-3$, named as $\mathrm{M} 1$ and $\mathrm{M} 2$, respectively; and one austenitic stainless steel, AISI 316L, used as reference sample, named A, have been studied. The chemical compositions of the alloys are presented in Table 1. Their corresponding heat treatments and microstructures are presented elsewhere [16].

Samples were provided in form of disks $22 \mathrm{~mm}$ in diameter and $5 \mathrm{~mm}$ thick. Specimens were wet-ground with 220 to $4000 \mathrm{SiC}$ paper and further polished with $3 \mu \mathrm{m}$ diamond suspension up to a mirror like finishing $\left(R_{a}=0.1 \mu \mathrm{m}\right)$. After polishing, the samples were cleaned with ethanol in an ultrasonic bath and dried using a stream of compressed air.

Table 1. Chemical composition of different stainless steels (wt. \%)

\begin{tabular}{cccccccc}
\hline Material & $\mathrm{C}$ & $\mathrm{Ti}$ & $\mathrm{V}$ & $\mathrm{Cr}$ & $\mathrm{Ni}$ & $\mathrm{Mo}$ & $\mathrm{Fe}$ \\
\hline & & & & & & & \\
A & 0.02 & 0.003 & - & 16.8 & 10.6 & 2.6 & Bal. \\
& & & & & & & \\
M1 & 0.01 & 0.3 & - & 12 & 11 & 2 & Bal. \\
M2 & 0.12 & - & 0.3 & 12 & 2.5 & 1.6 & Bal. \\
\hline
\end{tabular}

\subsection{Mechanical characterization}

The Vickers hardness of the studied stainless steels have been measured by means of a microdurometer Duramin of Struers (Germany) applying $1 \mathrm{Kg}$ during $30 \mathrm{~s}$. Elastic modulus was obtained using an ultrasonic equipment Karl Deutsch - Digital Ecograph (Germany). The measurements were repeated three times for each material. Yield strength data was provided by the manufacturer, which has been obtained following the stadandard ASTM A514 standard [17] at the offset yield point of $0.2 \%$. 


\subsection{Electrochemical equipment and solution}

The basic cell configuration with three electrodes was used for carrying out the electrochemical measurements. The electrode system was formed by the working electrode (sample to study), the reference electrode $\mathrm{Ag} / \mathrm{AgCl}(3 \mathrm{M} \mathrm{KCl})$ and the platinum wire as counter electrode. The standard potential of the reference electrode is $205 \mathrm{mV}$ with respect to the Standard Hydrogen Electrode (SHE) at $25^{\circ} \mathrm{C}$.

The electrolyte was a $3 \% \mathrm{NaCl}$ solution $(\mathrm{pH}=6)$. Tests were conducted in naturally aerated solution at room temperature with an exposed sample area of $2.56 \mathrm{~cm}^{2}$.

\subsection{Polarization curves}

After mounting the samples on the electrochemical cell, they were kept at a cathodic potential of $-1.1 \mathrm{~V}$ during $300 \mathrm{~s}$. Afterwards samples were left for $1800 \mathrm{~s}$ without any polarization at open circuit potential (OCP). Cathodic potentiodynamic polarization curves were performed by scanning the potential from OCP to $-1.1 \mathrm{~V}$ at a scan rate of $1 \mathrm{mV} / \mathrm{s}$. Tests were repeated twice in order to check for reproducibility.

\subsection{Tribocorrosion test}

A ball-on-disk tribometer Microtest (Spain) was used to carry out the tribocorrosion experiments, which configuration was explained elsewhere [18]. Figure 1 shows a schema of the experimental set-up. An alumina ball of $3 \mathrm{~mm}$ radius was used as a counterpart and the applied normal load was $5 \mathrm{~N}$ with a maximum and average initial contact pressure of $1236 \mathrm{MPa}$ and $824 \mathrm{MPa}$, respectively. The sliding velocity was set at $60 \mathrm{rpm}(18.8 \mathrm{~mm} / \mathrm{s})$ in all tests during $3600 \mathrm{~s}$. 


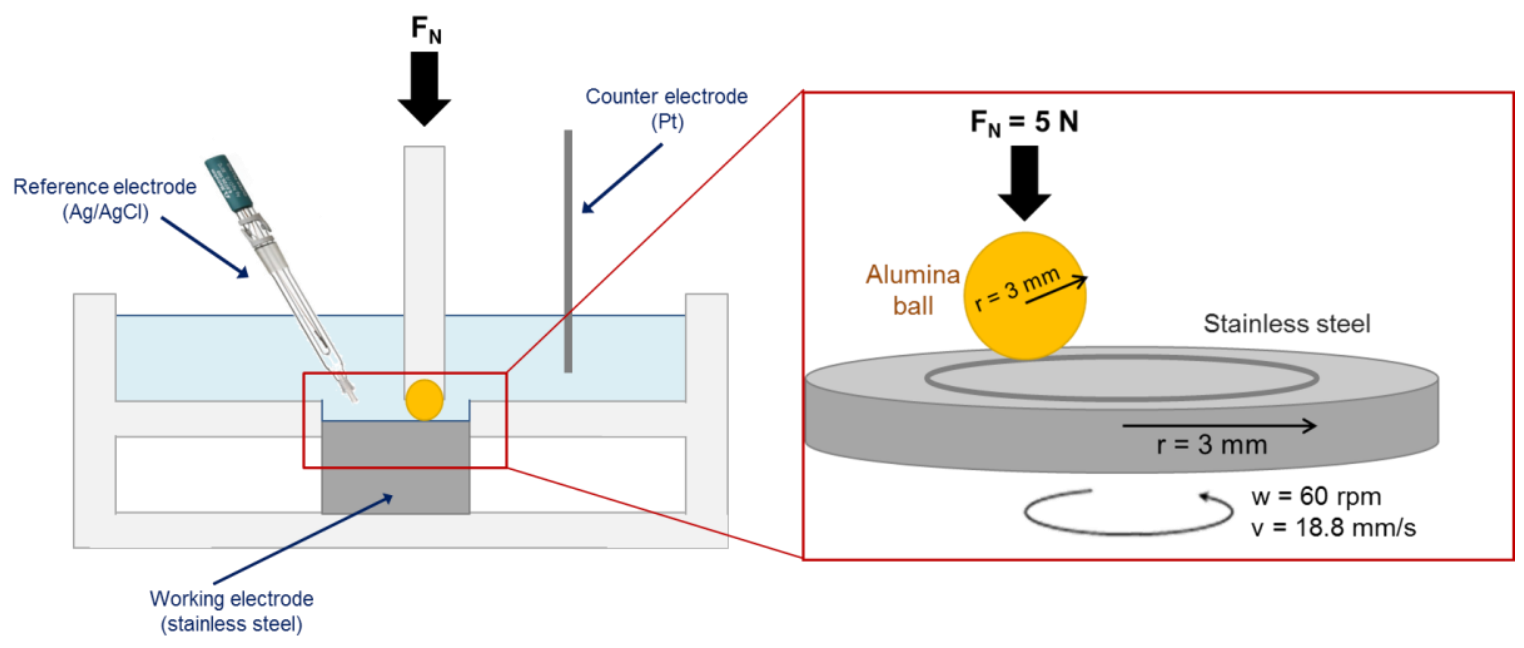

Figure 1. Experimental set-up of the tribometer with a horizontal electrochemical cell.

Two different tribocorrosion tests were carried out, open circuit potential (OCP) and potentiostatic at two different applied potentials:

- Tribocorrosion tests at OCP consist in recording the potential versus time. First, the OCP was measured for $3600 \mathrm{~s}$ without motion for stabilization and then the sliding started for $3600 \mathrm{~s}$ while the OCP was maintained. Once the sliding was stopped, the open circuit potential was maintained for $1200 \mathrm{~s}$.

- Tribocorrosion tests were carried out at two different applied potentials: cathodic potential $(-1 \mathrm{~V})$ and passive potential $(-0.1 \mathrm{~V})$. In this case, the response in current was recorded versus time. Initially, once the potential was applied, the current was recorded for $3600 \mathrm{~s}$ without motion and then the sliding started for $3600 \mathrm{~s}$ while the potential was maintained and the response in current was registered. Once the sliding was stopped, the potential was maintained for $1200 \mathrm{~s}$.

A cathodic polarization was done by applying a potential of $-1 \mathrm{~V}$ for $300 \mathrm{~s}$ before all the tests. All tests were repeated twice $(n=2)$.

\subsection{Wear characterization}

Wear volumes were obtained by measuring three profiles across the wear track in each sample using a confocal microscope Olympus LEXT OLS3000 (Germany) with a resolution of $0.12 \mu \mathrm{m}$. The total wear volume $\left(\mathrm{V}_{\text {tot }}\right)$ was calculated 
by using the average area removed by sliding (wear track area, $A_{w t}$ ), which was obtained by the integration of values below zero within the wear track, multiplied by the wear track length I:

$$
V_{t o t}=A_{w t} \cdot l
$$

The wear coefficient $(K)$ was calculated from the following relationship, which relates the wear volume $(\mathrm{V})$ to the product of the sliding distance $(\mathrm{d})$ with the normal force $\left(F_{N}\right)$ :

$$
K\left(m m^{3} / N m\right)=\frac{V}{d F_{N}}
$$

In order to analyze the wear morphology, optical microscope Zeiss Axio Scope A1 (Germany) and a scanning electron microscope SEM JEOL6300 (Germany) were used to analyse wear tracks on the studied stainless steels and on the alumina counterpart. SEM measurements were carried out at $20 \mathrm{KV}$ and the working distance was $10 \mathrm{~mm}$. Some samples were observed using a Zeiss Auriga Compact system (Germany) which incorporates a focus ion beam (FIB) for cross sectioning the wear track and it was observed with a high resolution SEM. In this case, the SEM measurements were carried out at $5 \mathrm{KV}$ and the working distance was $5 \mathrm{~mm}$. The FIB probe intensity was $30 \mathrm{KV}: 50 \mathrm{pA}$. After the tribocorrosion tests, hardness inside the wear track was measured with the same procedure described in the mechanical characterization, section 2.2.

\section{Results}

Mechanical characterizationTable 2 shows the microhardness, the elastic modulus and the yield strength values of the stainless steels. The martensitic stainless steels showed higher hardness compared to the austenitic one $(A)$, around $500 \mathrm{HV}$. Elastic modulus are similar for all studied materials lying around $200 \mathrm{GPa}$ for all studied stainless steels, except for M1 which showed the lowest elastic modulus (187 GPa). The yield strength of the $\mathrm{A}(230 \mathrm{MPa})$ is much lower than the values obtained for M1 and M2 (1610 and $975 \mathrm{MPa}$ respectively).

Table 2. Mechanical characterization of the studied stainless steels. 


\begin{tabular}{cccc}
\hline & $\begin{array}{c}\text { Microhardness } \\
(\mathbf{H V})\end{array}$ & $\begin{array}{c}\text { Elastic modulus } \\
(\mathbf{G P a})\end{array}$ & $\begin{array}{c}\text { Yield strength } \\
(\mathbf{M P a})\end{array}$ \\
\hline A & $247 \pm 11$ & $205 \pm 6$ & 230 \\
M1 & $535 \pm 10$ & $187 \pm 18$ & 1610 \\
M2 & $444 \pm 9$ & $212 \pm 3$ & 975 \\
\hline
\end{tabular}

\subsection{Polarization behavior}

The cathodic polarization curves of the studied materials are shown in Figure 2. Below potentials of $-0.15 \mathrm{~V}$ current density linearly increases (in absolute value) with the applied potential Therefore, in this potential domain the cathodic Tafel equation (1) can be obtained through the linear regression of the current versus the applied potential of the cathodic polarization curves:

$$
\eta=a_{c}-b_{c} \log (i)
$$

where $\eta$ is the overpotential ( $\left.E-E_{\text {corr }}\right), a_{c}$ and $b_{c}$ the Tafel coefficients and $i$ the current density. By carrying out the linear regression, the Tafel coefficients $\left(a_{c}\right.$ and $\left.b_{c}\right)$ were obtained and summarized in

Table 3. The corrosion potential $\left(\mathrm{E}_{\mathrm{corr}}\right)$ was determined as the potential at which the current changes from anodic (positive) to cathodic (negative) value in the potentiodynamic curve.

The polarization behavior is similar in all samples, except for the austenitic material which shows higher corrosion potential. The Tafel coefficients are similar in all the studied materials, $b_{c}$ values are around $0.2 \mathrm{~V}$ and $a_{c}$ varied from -1.5 to $-1.2 \mathrm{~V}$. 


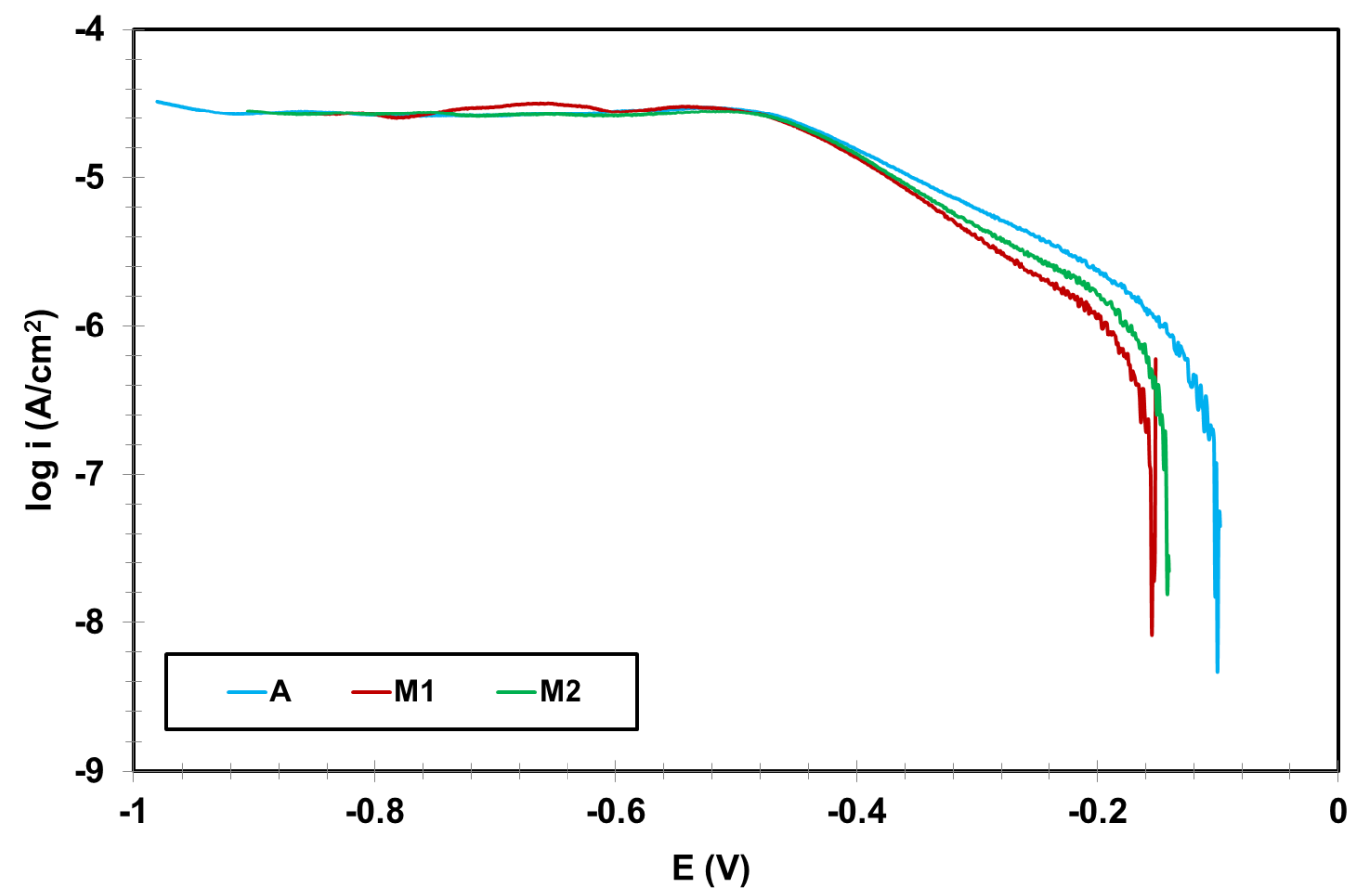

Figure 2. Cathodic polarization curves of the studied stainless steels in $3 \% \mathrm{NaCl}$ solution at room temperature.

Table 3. Corrosion potential and Tafel constants extracted from the linear regression of the cathodic polarization curves of the studied stainless steels in $3 \% \mathrm{NaCl}$ solution at room temperature.

\begin{tabular}{cccc}
\hline & $\mathbf{E}_{\text {corr }}(\mathbf{V})$ & $\mathbf{b}_{\mathbf{c}}(\mathbf{V})$ & $\mathbf{a}_{\mathbf{c}}(\mathbf{V})$ \\
\hline $\mathbf{A}$ & $-0.10 \pm 0.00$ & $0.24 \pm 0.01$ & $-1.47 \pm 0.04$ \\
$\mathbf{M} 1$ & $-0.16 \pm 0.01$ & $0.20 \pm 0.02$ & $-1.23 \pm 0.09$ \\
M2 & $-0.14 \pm 0.01$ & $0.21 \pm 0.00$ & $-1.31 \pm 0.02$ \\
M3 & $-0.14 \pm 0.00$ & $0.19 \pm 0.00$ & $-1.18 \pm 0.01$ \\
\hline
\end{tabular}

\subsection{Electrochemical response to sliding}

\subsubsection{Potential evolution under sliding conditions}

Figure 3 shows the evolution of the potential with time of the stainless steels. Before sliding, the values of the OCP indicate the presence of a passive film on the samples, which abruptly decrease after the initiation of the sliding. When rubbing the thin oxide layer is removed, leaving a depassivated area in contact with the electrolyte [3]. The OCP evolution observed during rubbing results from the galvanic couple established between the depasivated and still passive areas, as suggested by Vieira et al. [7]. Once the sliding is stopped, the potential increases to more anodic values due to the repassivation of the worn zone. Similar behaviour is observed in all the studied stainless steels. 


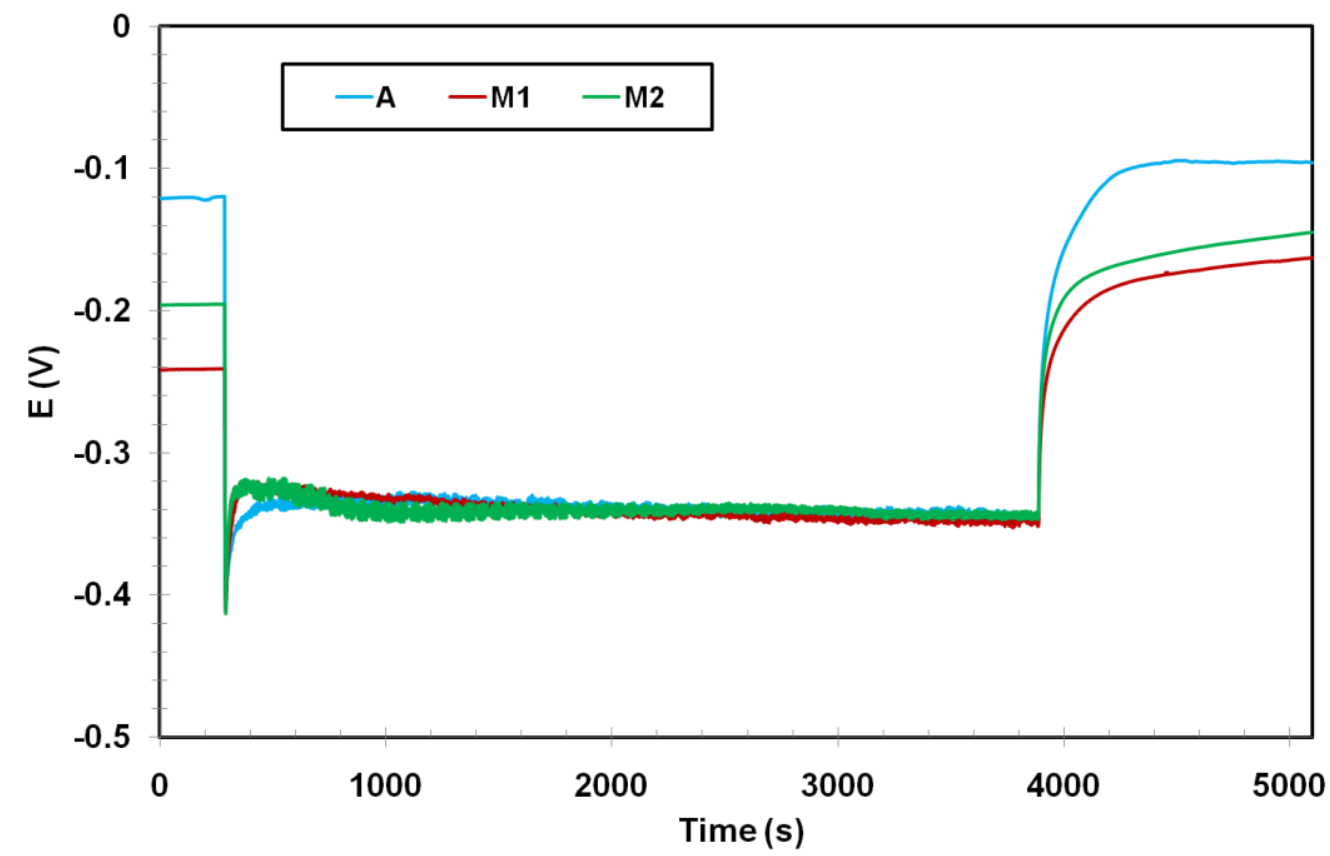

Figure 3. Evolution of the potential with time during of the studied stainless steels during tribocorrosion tests at OCP $\left(\mathrm{F}_{\mathrm{N}}=5 \mathrm{~N}\right)$.

\subsubsection{Current during rubbing}

Analogously to the previous section, Figure $4 \mathrm{a}$ and $2 \mathrm{~b}$ show the evolution of the measured current with time at cathodic $(-1 \mathrm{~V})$ and passive potentials $(-0.1 \mathrm{~V})$, respectively.

At the cathodic applied potential of $-1 \mathrm{~V}$, current increases (in absolute value) when rubbing starts. In all cases a trend of current decrease with time was observed during the sliding. This trend is more pronounced in the M1 material. Under the studied conditions, neutral and aerated solution, at $-1 \mathrm{~V}$ the stable form of chromium is $\mathrm{Cr}_{2} \mathrm{O}_{3}$. When rubbing, the thin oxide layer is removed and it leaves a depassivated area in contact with the electrolyte. Because at that potential the current is given by the cathodic reactions, oxygen and water reduction, and they are critically dependent on the surface state (passive layers inhibit oxygen reduction reaction), rubbing causes an enhancement of the cathodic current.

At applied passive potential, the different studied stainless steels are passive, which is characterized by the low values of the current (below $0.5 \mu \mathrm{A}$ ). An abrupt increase of the current is observed at the beginning of sliding due to the mechanical detachment of the passive film [3]. Current continues slightly increasing during sliding. The increase of the anodic current is higher in the martensitic stainless steels 
when compared to the austenitic one, although higher current oscillations are observed in the A test. Once rubbing stopped, the current decreased to the initial values due to the repassivation of the worn area. The same behavior in different passive systems was observed by different authors [19][20][21].

a

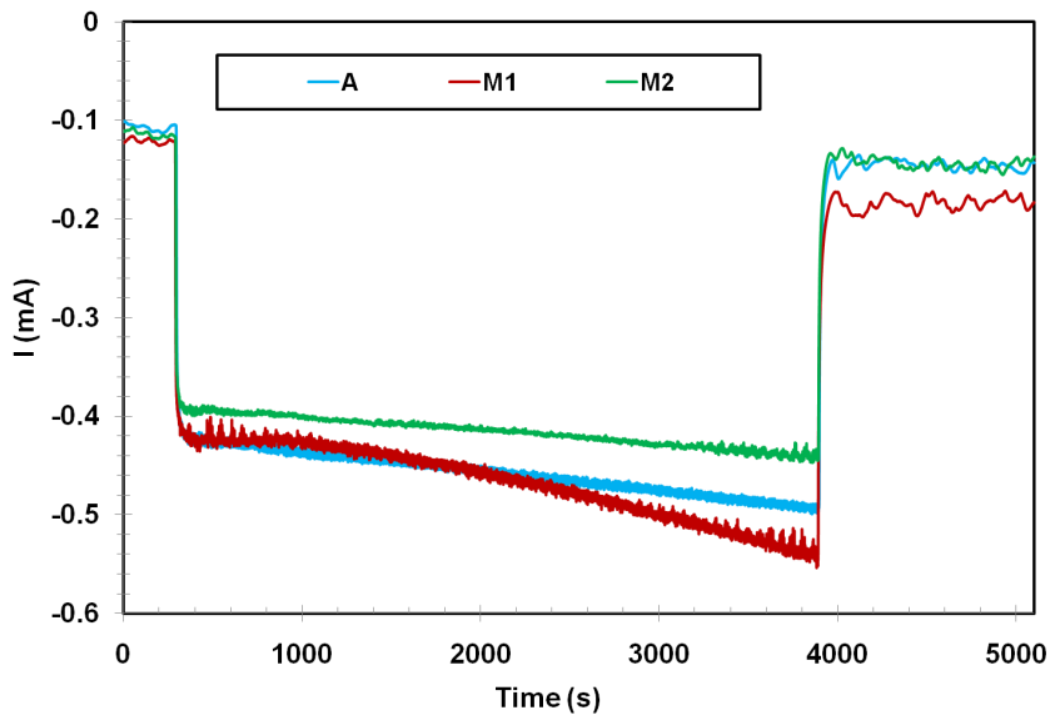

b

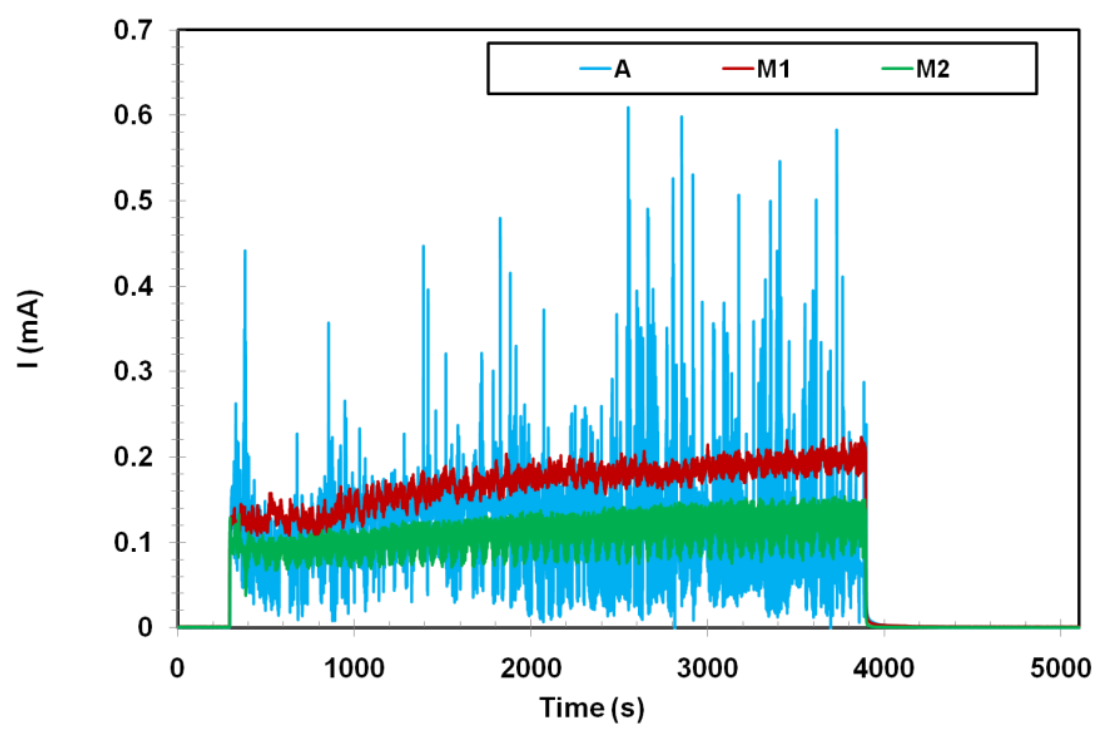

Figure 4. Evolution of the measured current with time of the studied stainless steels during tribocorrosion tests at (a) cathodic potential $-1 \mathrm{~V}$ and (b) passive potential $-0.1 \mathrm{~V}$ $\left(F_{N}=5 N\right)$.

\subsection{Friction and wear quantification}

Figure 5 shows the evolution of the friction coefficient with time for all studied stainless steels at $-0.1 \mathrm{~V}$. The values of the coefficient of friction are constant 
throughout the tests, thus the average values of the coefficient of friction of two different tests are listed in

Table 4 for all materials at all the studied potentials. In general, all coefficients of friction lied between 0.35 and 0.47 . These values are less material dependent at passive potential $(-0.1 \mathrm{~V})$ than the other potentials, suggesting that the passive film play a role in the wear and friction behavior of the studied stainless steels.

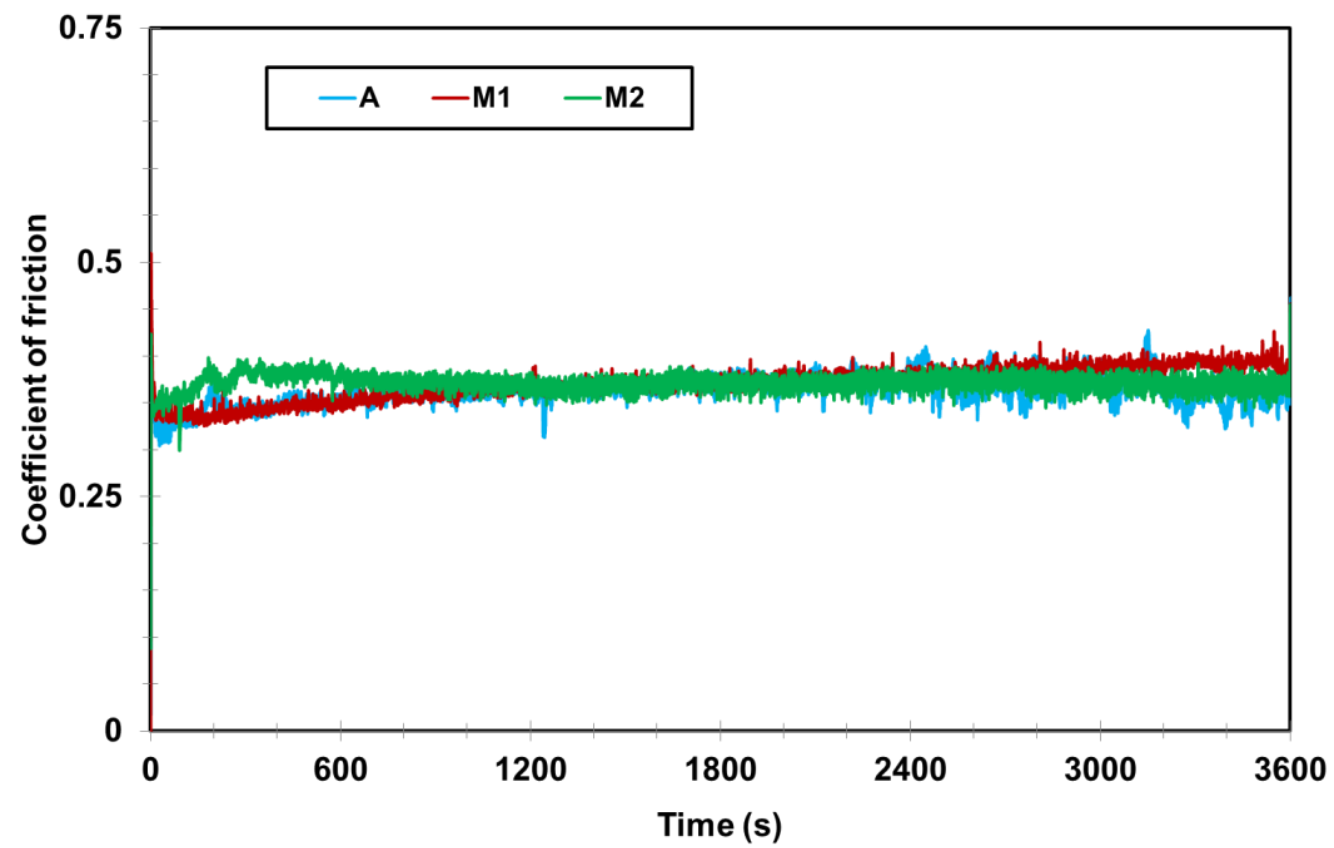

Figure 5. Evolution of the friction coefficient with time for all studied stainless steels $(E=-0.1 \mathrm{~V})$.

Table 4. Average values of the friction coefficient $(\mu)$ of the studied stainless steels at different applied potentials during sliding.

\begin{tabular}{cccc}
\cline { 2 - 4 } & \multicolumn{3}{c}{$\boldsymbol{\mu}$} \\
\hline & $\mathbf{- 1} \mathbf{~ V}$ & OCP & $-\mathbf{0 . 1} \mathbf{~ V}$ \\
\hline A & $0.41 \pm 0.04$ & $0.47 \pm 0.00$ & $0.36 \pm 0.04$ \\
M1 & $0.44 \pm 0.03$ & $0.36 \pm 0.01$ & $0.36 \pm 0.04$ \\
M2 & $0.39 \pm 0.00$ & $0.42 \pm 0.02$ & $0.39 \pm 0.01$ \\
\hline
\end{tabular}

Table 5 shows the microhardness values of the stainless steels measured after the tribocorrosion tests inside the wear track under the different electrochemical conditions and the corresponding increase in hardness with respect to the bulk material (hardness outside the wear track) expressed as \% percentage and the ratio 
between the hardness inside and outside the wear track $\left(\mathrm{H}_{\text {in }} / \mathrm{H}_{\text {out }}\right)$. It is observed a general increase of the hardness after the tribocorrosion tests due to the work hardening induced by the sliding. This increase in hardness is potential dependent, indeed 10, 15 and $20 \%$ of increase was observed at the cathodic, OCP and passive potentials respectively, when compared to the hardness of the bulk material (Table 2). The ratio between the hardness inside and outside the wear track $\left(H_{\text {in }} / H_{\text {out }}\right)$ lies from 1.10 to 1.31 for all stainless steels.

Table 5. Microhardness of stainless steels after the tribocorrosion tests in the wear track at the different electrochemical conditions, the relative increase following the wear test and the ratio $\mathrm{H}_{\text {in }} / \mathrm{H}_{\text {out }}$.

\begin{tabular}{cccc|ccc|ccc}
\hline & \multicolumn{3}{c|}{$-1 \mathbf{V}$} & \multicolumn{3}{c|}{ OCP } & \multicolumn{3}{c}{$-\mathbf{0 . 1} \mathbf{~ V}$} \\
\cline { 2 - 10 } & $\mathbf{H V}$ & $\%$ & $\mathbf{H}_{\text {in }} / \mathbf{H}_{\text {out }}$ & $\mathbf{H V}$ & $\%$ & $\mathbf{H}_{\text {in }} / \mathbf{H}_{\text {out }}$ & $\mathbf{H V}$ & $\%$ & $\mathbf{H}_{\text {in }} / \mathbf{H}_{\text {out }}$ \\
\hline A & $272 \pm 8.7$ & 9.2 & 1.10 & $283 \pm 6.5$ & 12.7 & 1.15 & $324 \pm 15.6$ & 23.8 & 1.31 \\
M1 & $588 \pm 10.6$ & 9 & 1.10 & $610 \pm 8.4$ & 12.3 & 1.14 & $662 \pm 16.6$ & 19.2 & 1.24 \\
M2 & $478 \pm 10.2$ & 7.1 & 1.08 & $526 \pm 14.3$ & 15.6 & 1.18 & $538 \pm 15.7$ & 17.5 & 1.21 \\
\hline
\end{tabular}

For the interpretation of the different tribocorrosion mechanisms which simultaneously take place generating material loss, four approaches to tribocorrosion are reported in the literature: the synergistic, the mechanistic, the third body and the nanochemical wear [22]. In this study, the mechanistic approach was considered, which distinguishes two main contributions: anodic dissolution (wear-accelerated corrosion, ( $\left.\mathrm{V}_{\text {wac }}\right)$ and mechanical removal of metal particles (mechanical wear, $\mathrm{V}_{\text {mech }}$ ) in the wear track [23]. Since the corrosion phenomenon outside the wear track can be considered negligible for the studied alloys (passive alloys), the overall material loss is simplified by the sum of the mechanical and wear accelerated corrosion volumes, as calculated in a previous study [18]. An example of the surface profile of the M2 after the potentiostatic tribocorrosion test at $-0.1 \mathrm{~V}$ is shown in ¡Error! No se encuentra el origen de la referencia..

The wear accelerated corrosion at OCP has been determined according to the model proposed by Vieira et al [7] and validated by different authors for different materials [24][25][26][27]. This model takes into account the cathodic kinetics (the Tafel constants extracted from the cathodic polarization, $a_{c}$ and $b_{c}$ ) and the corrosion potential of the alloys $\left(E_{c o r r}\right)$, the potential measured during sliding $\left(E_{c}\right)$ and the anode 
to cathode areas ratio $\left(A_{a}\right.$ and $A_{c}$, respectively). From this model, the anodic current passing through the wear track $\left(\mathrm{i}_{\mathrm{a}}\right)$ was calculated by using the following equation:

$$
\log i_{a}=\frac{E_{c o r r}-E_{c}+a_{c}}{b_{c}}-\log \left(\frac{A_{a}}{A_{c}}\right)
$$

In order to apply this model, the electrochemical parameters from Table 3 have been considered. The anodic area $\left(A_{a}\right)$ was calculated by the confocal profile at the end of the experiment and the cathode area $\left(A_{c}\right)$ can be approximated by the sample area $\left(2.56 \mathrm{~cm}^{2}\right)$.

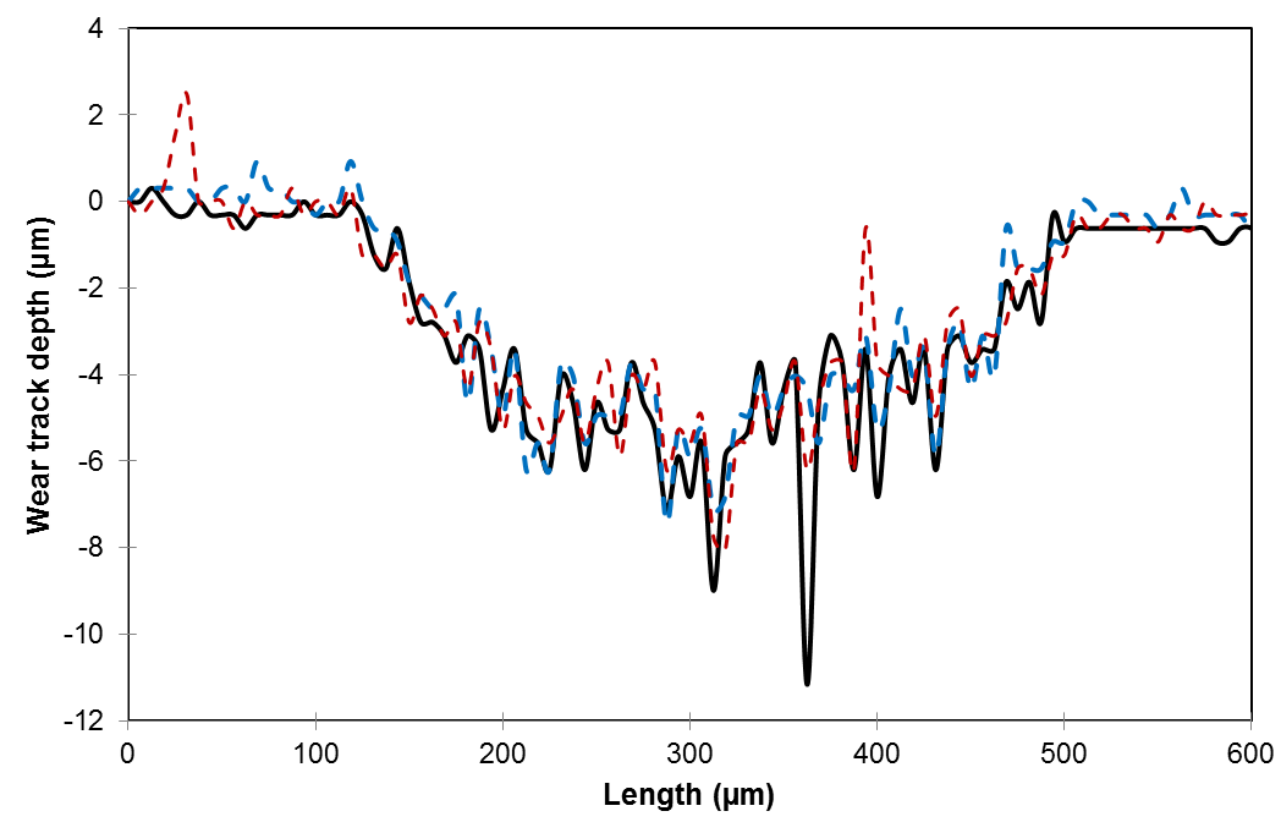

Figure 6. Surface profile of the M2 (overlapped one can find two profiles in dashed lines corresponding to two different repetitions of the test under the same conditions) after potentiostatic tribocorrosion test at $-0.1 \mathrm{~V}$.

The obtained wear volumes are presented in Table 6. At cathodic potential, the wear volume of all the studied materials is very similar and the lowest among the different electrochemical conditions. $V_{\text {mech }}$ increases at OCP and at $-0.1 \mathrm{~V}$ when compared to the value obtained at the cathodic potential. Under passive conditions (OCP and $-0.1 \mathrm{~V}) \mathrm{V}_{\text {wac }}$ increases with the increase in the applied potential for all materials. Total wear is similar for all martensitic alloys, except for the M1, which shows the lowest wear volume at OCP and the highest at $-0.1 \mathrm{~V}$. 
Table 6. Average wear volumes $\left(\cdot 10^{-3} \mathrm{~mm}^{3}\right)$ of the studied stainless steels.

\begin{tabular}{cc|ccc|ccc}
\hline & $\mathbf{- 1 V}$ & \multicolumn{3}{|c|}{ OCP } & \multicolumn{3}{c}{$\mathbf{- 0 . 1 V}$} \\
\cline { 2 - 8 } & $\mathbf{V}_{\text {tot }}$ & $\mathbf{V}_{\text {tot }}$ & $\mathbf{V}_{\text {mech }}$ & $\mathbf{V}_{\text {wac }}$ & $\mathbf{V}_{\text {tot }}$ & $\mathbf{V}_{\text {mech }}$ & $\mathbf{V}_{\text {wac }}$ \\
\hline $\mathbf{A}$ & $1.4 \pm 0.5$ & $11.7 \pm 2.3$ & $9.5 \pm 2.4$ & $2.1 \pm 0.1$ & $19.3 \pm 4.0$ & $15.7 \pm 3.2$ & $3.7 \pm 0.8$ \\
$\mathbf{M 1}$ & $1.4 \pm 0.3$ & $7.8 \pm 1.7$ & $6.3 \pm 1.7$ & $1.5 \pm 0.1$ & $25.0 \pm 2.1$ & $18.7 \pm 2.1$ & $6.3 \pm 0.1$ \\
$\mathbf{M} 2$ & $1.4 \pm 0.4$ & $17.3 \pm 0.56$ & $15.6 \pm 0.7$ & $1.7 \pm 0.2$ & $18.2 \pm 0.6$ & $13.8 \pm 0.2$ & $4.4 \pm 0.4$ \\
\hline
\end{tabular}

\subsection{Wear morphology}

Wear was analysed with optical and SEM microscopy in and around the wear track after tribocorrosion tests. Figure 7 shows the optical and SEM micrographs of the wear track and outside the wear track of the M1 sample at the end of the different tribocorrosion tests. There are not big differences in the wear morphology between the different alloys. The optical images of the wear track are presented in Figure 7a, showing that the width of the wear track increases with the applied potential. SEM micrographs in Figure 7b show high plastic deformation in which scratches are also observed due to wear particles inducing a three body phenomena and abrasion on the wear track [19]. Wear debris, sizing around 0.5-1 $\mu \mathrm{m}$ are observed inside the wear track. The amount of particles increases with the decrease in potential. Smoother surface appears when the potential increases. Wear particles ranging from 1 to $5 \mu \mathrm{m}$ are observed outside the wear track, Figure 7c. Larger particles are formed by agglomeration of smaller particles of debris, and this is mainly observed at OCP.

Figure 8 shows the optical images of the alumina balls at the end of the tests for the M2 sample. Transferred metal in the surface of the alumina ball is observed. Similar images were obtained in all the tests.

SEM micrographs of a cross section of the wear track (perpendicular to the sliding direction) obtained by focus ion beam (FIB) are presented in Figure 9. They show the subsurface microstructure of M1 under different electrochemical conditions: cathodic (Figure 9a), OCP (Figure 9b) and passive potential (Figure 9c). A tribological transformed zone near the worn surface area is observed, in which a 
layer ranging from 1 to $1.5 \mu \mathrm{m}$ of thickness is characterized by a grain refinement, corresponding to a strain hardened material. This phenomenon was observed before by several authors in stainless steels [28][8][29] and it was attributed to the "rearrangement of dislocations introduced by frictional strain" [30] which depends of the prevailing electrochemical conditions. This effect will be discussed afterwards. In some cases, cracks were observed few nanometers below the surface due to fatigue mechanism.
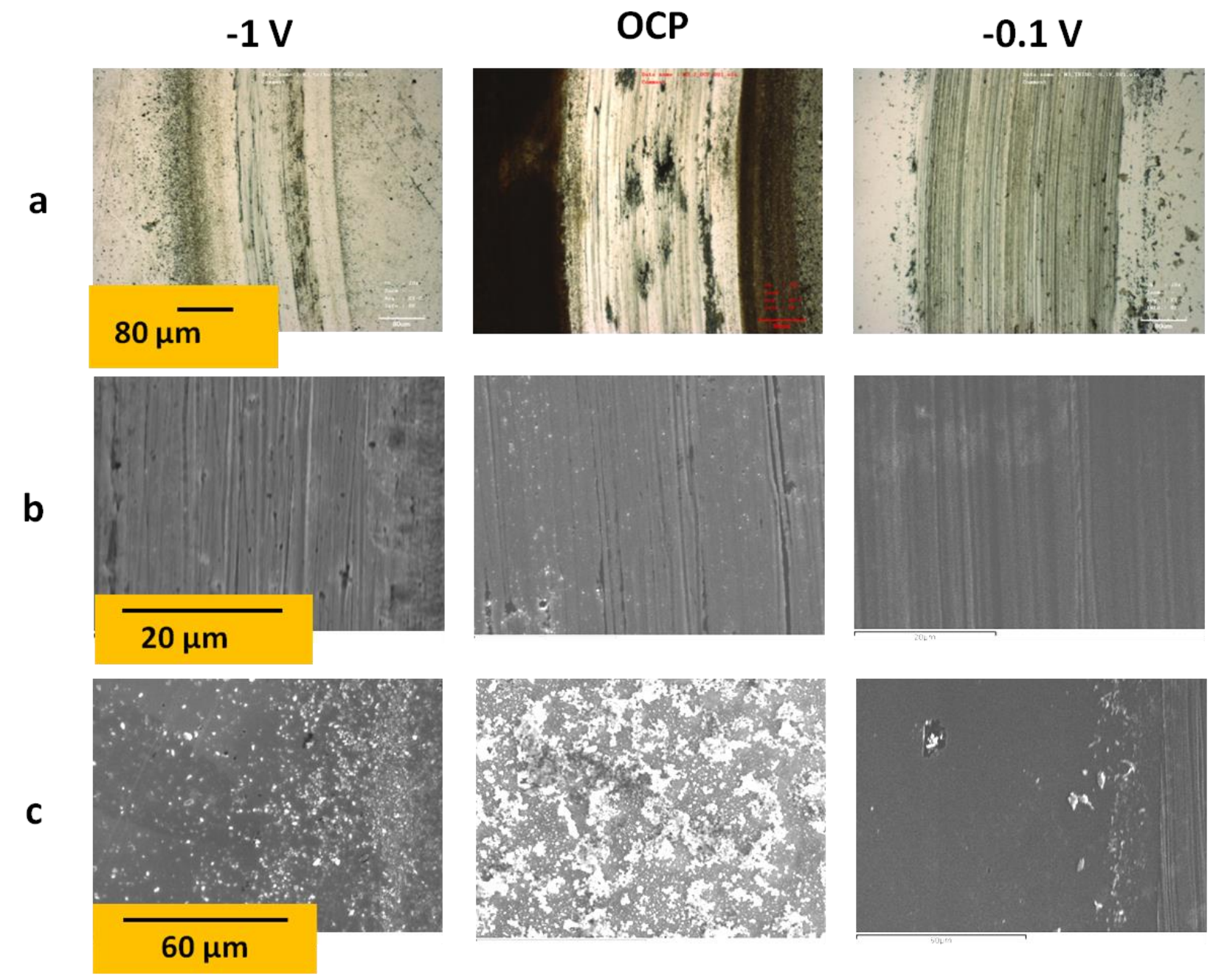

Figure 7.Optical (a) and SEM micrographs (b) of the wear track and the outside the wear track (c) of the $\mathrm{M} 1 \mathrm{sample}$ at the end of the different tribocorrosion tests $\left(\mathrm{F}_{\mathrm{N}}=5 \mathrm{~N}\right)$. 
$-1 \mathrm{~V}$

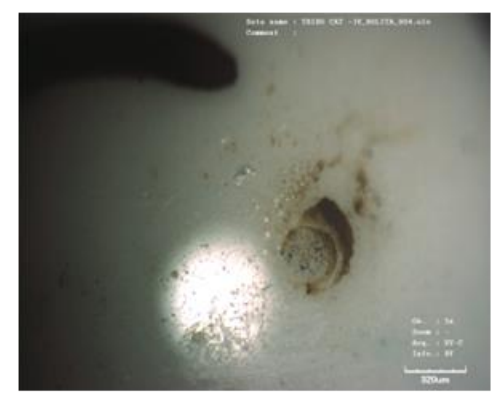

OCP

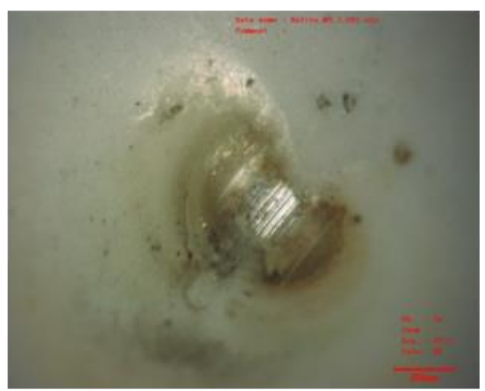

$-0.1 \mathrm{~V}$

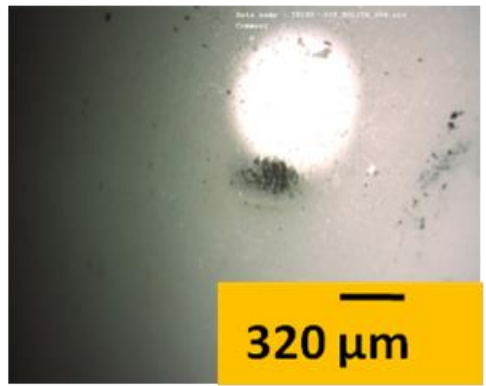

Figure 8. Optical images of the alumina balls at the end of the different tribocorrosion tests of the M2 sample $(\mathrm{FN}=5 \mathrm{~N})$. 


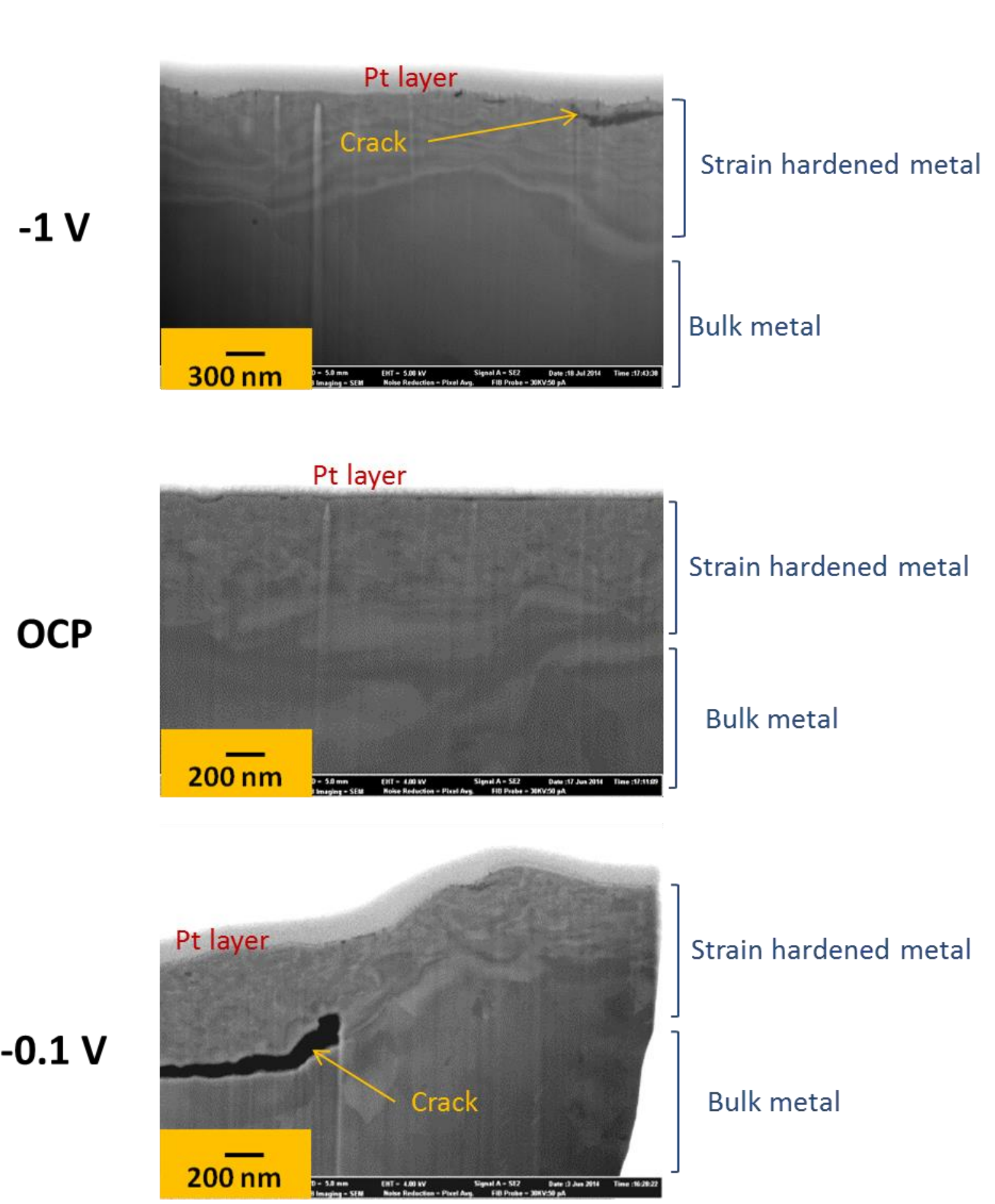

Figure 9.FIB transversal cross-section of wear track of $\mathrm{M} 1$ at (a) cathodic, (b) OCP and (c) passive potential after tribocorrosion tests $\left(\mathrm{F}_{\mathrm{N}}=5 \mathrm{~N}\right)$. 


\section{Discussion}

\subsection{Effect of hardening on wear}

Hardening is an important phenomenon that has to be taken into account when analyzing the wear mechanisms. It is an indicator of accumulated strain, which is known to promote wear according to existing low cycle fatigue and ratcheting models [31]. The repeated sliding cycles leads to a surface and subsurface tribologically transformed zone together with a change in the mechanical properties of the worn area, i.e. increase in hardness due to the strain hardening. Figure 10 shows the wear volumes as a function of the $\mathrm{H}_{\text {in }} / \mathrm{H}_{\text {out }}$ ratio (Table 5). From this figure, an increase in wear volume can be observed with the increase in the $\mathrm{H}_{\text {in }} / \mathrm{H}_{\text {out }}$ ratio between 1.10 and 1.25 (which corresponds to a relative increase in hardness around $10.5 \%)$. In this range of hardening, the trend indicates that both mechanical and wear accelerated corrosion volumes increase, thus that a more hardened surface leads to higher wear loss. However, above a $\mathrm{H}_{\text {in }} / \mathrm{H}_{\text {out }}$ ratio of 1.25 , the wear volumes stop increasing and a wear volume threshold could be distinguished. The exact explanation of this threshold is still a matter of discussion and further investigations would be needed to clarify this point.

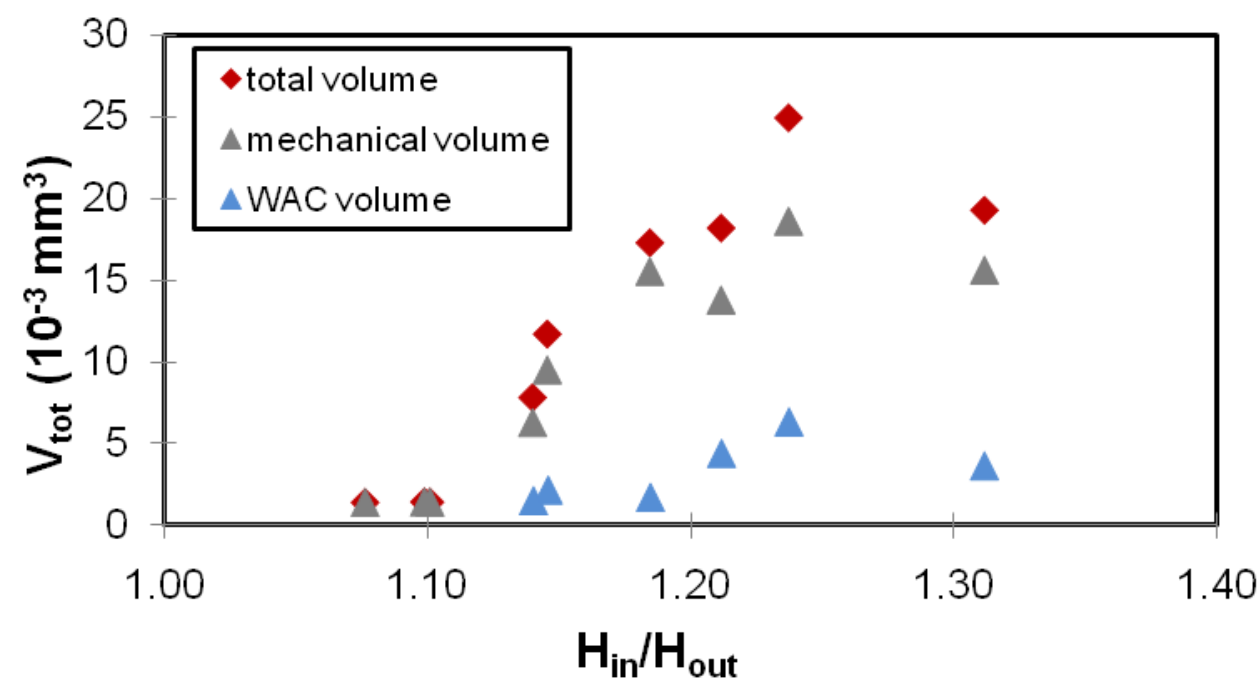

Figure 10. Total wear volumes as a function of the hardness ratio between hardness inside the wear track $\left(\mathrm{H}_{\text {in }}\right)$ and the hardness of the bulk material $\left(\mathrm{H}_{\text {out }}\right)$. 


\subsection{Effect of electrochemical conditions on wear}

Figure 11 shows the wear cofficient $(\mathrm{K})$ as a function of the applied potential of the studied stainless steels. Wear increases with the applied potential and the mechanical wear is the mechanism that most contributes to the total wear (Figure 11). Indeed, the mechanical wear represents the $100 \%$ of the total wear at cathodic potential $(-1 \mathrm{~V})$, when no corrosion takes place, between the $80-90 \%$ at OCP and between $70-80 \%$ at passive potential $(-0.1 \mathrm{~V})$. Total wear is one order magnitude lower at cathodic potentials than at anodic ones due to the contribution of wear accelerated corrosion, Figure $8 \mathrm{~b}$, at passive potentials (OCP and $-0.1 \mathrm{~V}$ ) but also because of the increase of mechanical wear, Figure 8c.

From the obtained results, it has been observed that the applied potential has also an influence on the near surface plastic behavior. From the micrographs presented in Figure 9, differences in the depth of the nano-cristalline layer at the different applied potentials can be observed. At cathodic potentials, this layer ranges from $200 \mathrm{~nm}$ to $1 \mu \mathrm{m}$; at OCP from 1 to $1.5 \mu \mathrm{m}$ and at passive potential from 1.5 to $2 \mu \mathrm{m}$. On the other hand, smaller grains were observed at passive potential due to the grain refinement under low-cycle fatigue. Hardness in the wear track (Table 5) also increased from $10 \%$ with respect the hardness of the bulk material at cathodic potentials to $20 \%$ at passive potentials.

Thus, the applied potential affects both, the wear accelerated corrosion but also the mechanical response of the tribocorrosion behavior, as already reported by different authors [25][29]. Some of these authors investigated the effect of the applied potential on the deformation behavior of different austenitic and duplex stainless steels and they confirmed that the presence of a passive film can critically affect the plastic deformation [28][29][32][8]. It is reported by Bidiville et al. [29] that "at cathodic potential the steel work hardens rapidly and develops a stable dislocation cell structure in the near surface region and the large plastic flow of metal surface results in relatively limited wear". However, at passive potential, "larger strain accumulation in the near surface region is attributed to the hindering by passive film of the annihilation of emerging dislocations and to possible active role of the passive film in the generation of dislocations". Mischler et al. concluded in their study [33] that the steels underwent either plastic flow accompanied by particle detachment or important 
subsurface cracking and delamination in presence of passive films: "applied mechanical straining and electrochemical potential conditions significantly influence the material loss rate and this is dependent on microstructural changes at the surface and subsurface affecting the mechanical properties controlled by the cyclic stressstrain and passive film integrity of the alloys". 
a

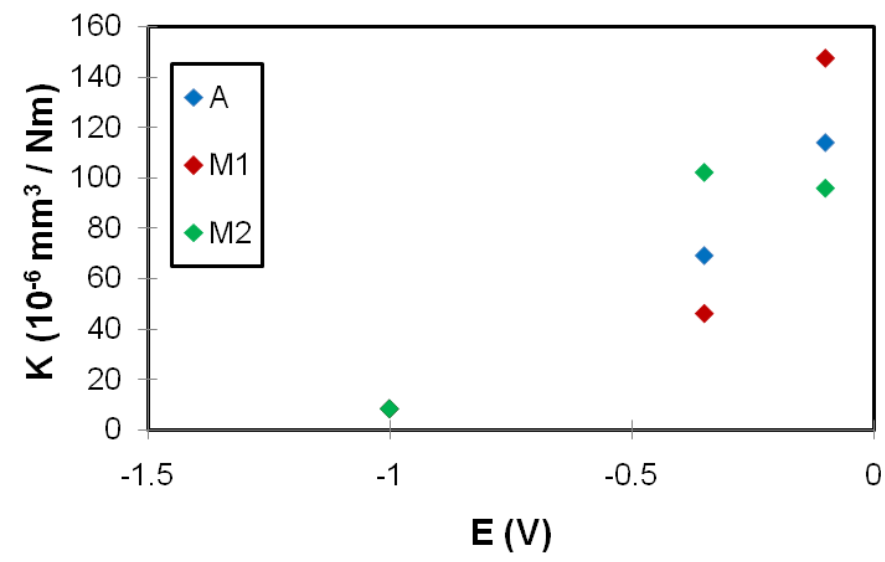

b

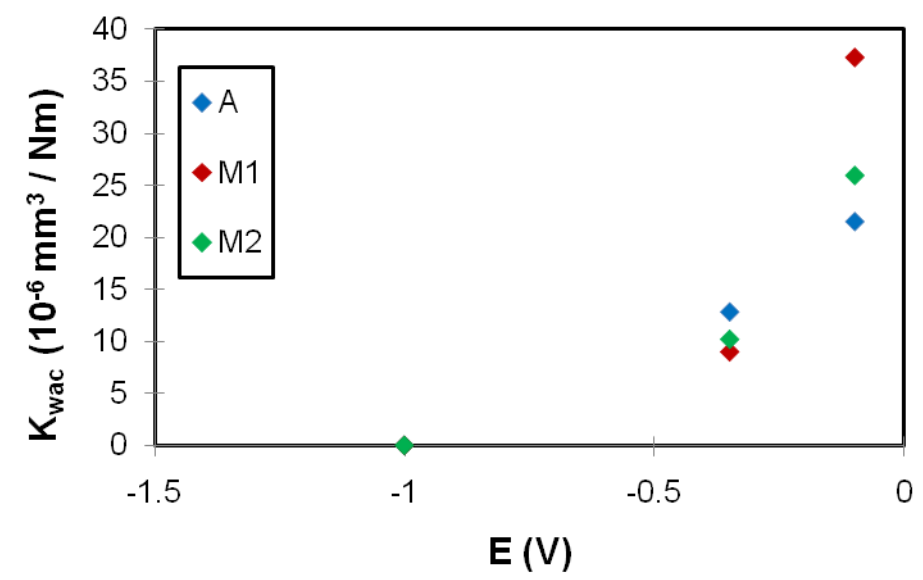

C

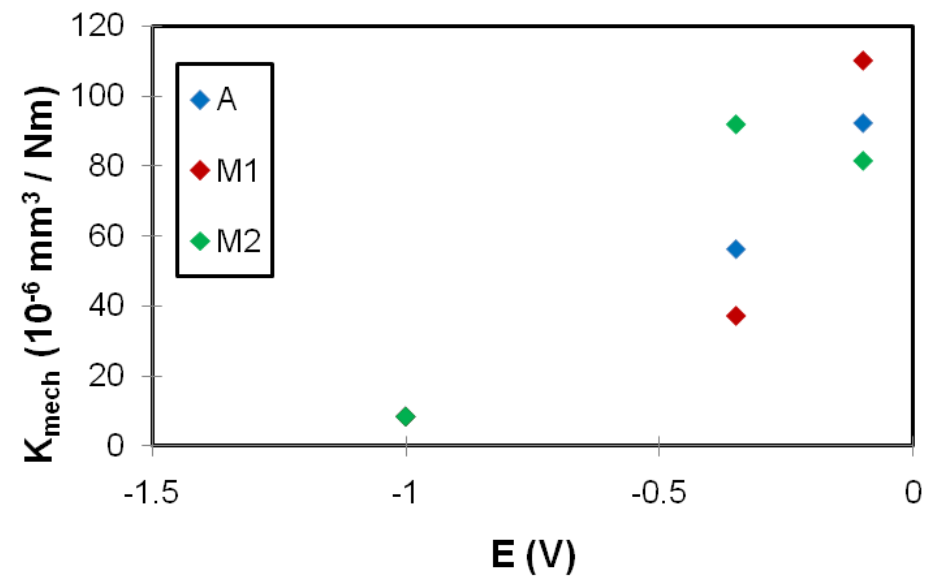

Figure 11. Wear rate $(K)$ as a function of the applied potential of the studied stainless steels: a) Total $(\mathrm{K})$, b) wear accelerated corrosion $\left(\mathrm{K}_{\mathrm{wac}}\right)$ and c) mechanical $\left(\mathrm{K}_{\text {mech }}\right)$ wear coefficient. 


\subsection{Wear mechanisms}

The high plastic deformation observed in Figure $7 \mathrm{~b}$ and Figure 9 in the surface and the subsurface of the wear track of the studied martensitic stainless steels suggests that a continuous removal of material from the interface of the material is taking place by large plastic strains. These plastic strains are gradually accumulated by the superposition of small, unidirectional shear strains that are generated at each load cycle, leading to a delamination wear mechanism. A schematic illustration of this wear mechanism is showed in Figure 12. This statement of delamination wear is confirmed by introducing the conditions of this study to the empirical wearmechanism maps for steel using a pin-on-disk configuration proposed by Lim and Ashby [34].

On the other hand, if those accumulated stresses are sufficiently high (generated by repeated sliding contact), they may also cause the growth of horizontal subsurface cracks. Indeed, cracks were found in some cases in the subsurface worn area of the studied materials, Figure 9. It is known that the studied stainless steels, with lath martensite microstructure and low carbon content [16], present low stacking fault energy which can be related to the trend of developing more dislocations during plastic deformation [35][36], thus favoring strain accumulation and probability of crack formation and propagation. However, no systematic crack evolution was found and further research is needed to understand the crack initiation.

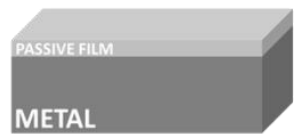

(a) Stable passive film

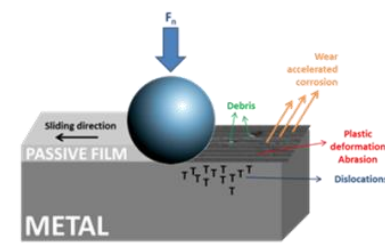

(b) Fracture of passive film and wear modification of the surface and subsurface

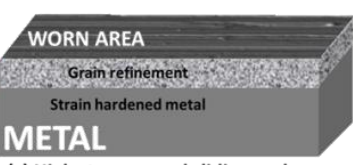

(c) High stresses and sliding cycles promote shakedown

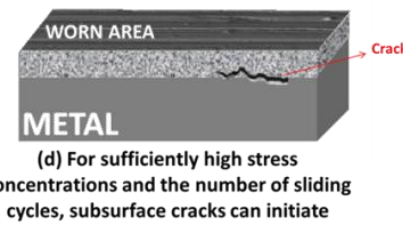

cycles, subsurface cracks can initiate

Figure 12. Schematic illustration of the wear mechanism of the studied martensitic stainless steels.

The different elasto-plastic response of metallic materials have been previously analyzed by Johnson and co-workers for linear and punctual repeated unidirectional sliding and rolling conditions [37][38]. Those authors elaborated shakedown maps in which elastic and plastic shakedown limits were expressed as a function of the load coefficient $\left(p_{0} / k\right)$ and the friction coefficient $\mu$, where $p_{0}$ is the 
maximum Hertzian pressure and $\mathrm{k}$ is the shear yield stress. The details of these elastic and shakedown limits were well discussed by Fouvry et al. [39] and a shakedown map taken from [31] is shown in Figure 10.

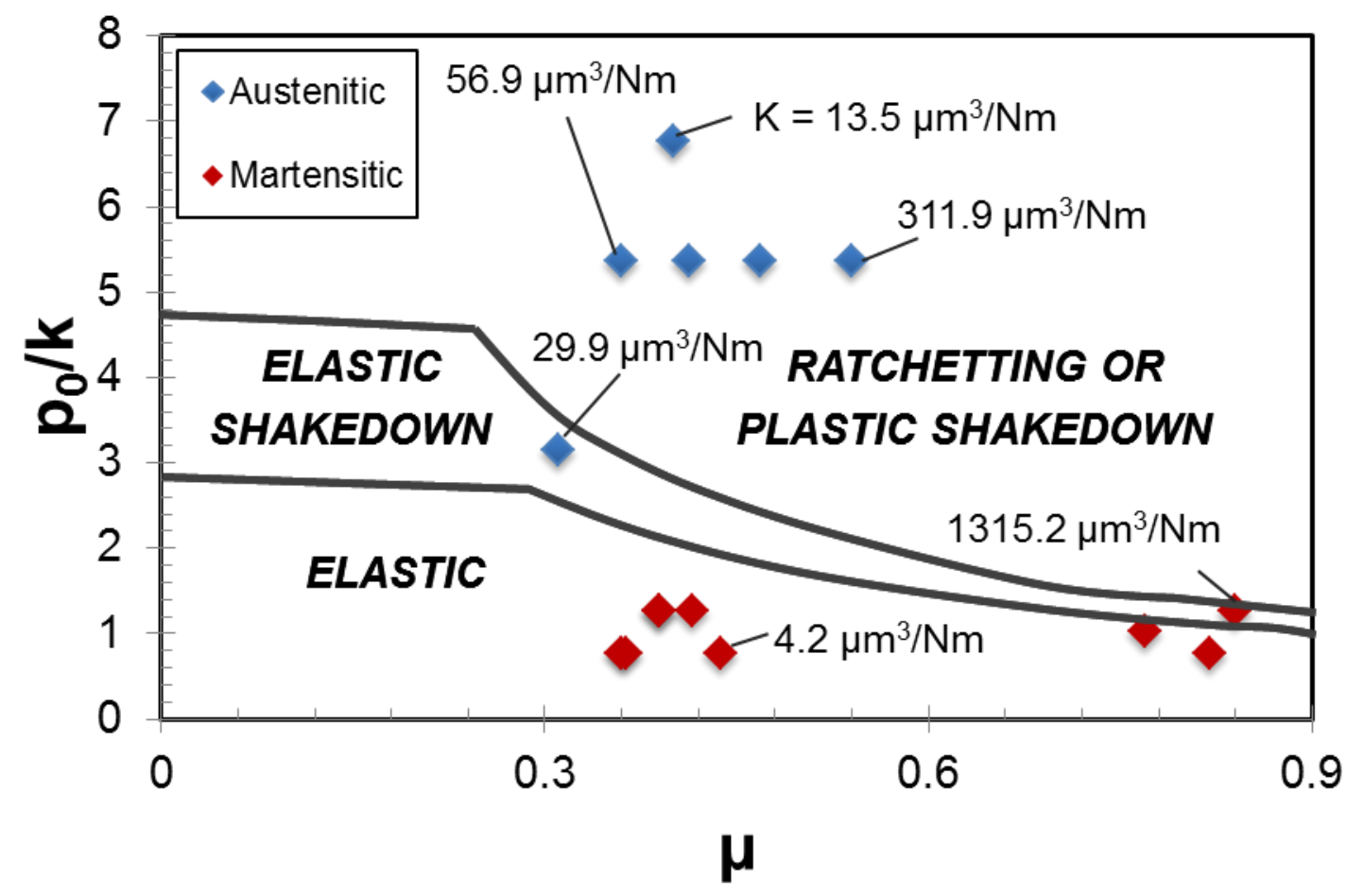

Figure 13. Wear map taking into account the elastic and elastic shakedown limits reported from [39].

In this figure, the experimental load coefficient versus the coefficient of friction obtained in the present work and the data from a previous work [16], corresponding to wear dry tests of the same materials, same experimental set-up and test conditions $\left(F_{N}=5 \mathrm{~N}\right)$ were also plotted. In principle, and according to the mechanisms delimited in the wear map of Figure 10, different wear mechanisms should be distinguished between austenitic and martensitic stainless steels. The former should show in both, wet and dry conditions, a ratcheting or shakedown mechanism for all applied loads, while the latter should show an elastic response. However, in the present experimental results, the same wear mechanisms of plastic deformation and shakedown was found for all studied stainless steels although they have different yield strength values (Table 2), thus different response according to the wear map of Figure 10. This is not surprising since the shakedown maps were obtained for entirely mechanic behavior and it does not take into account the involved 
mechanisms taking place in a tribocorrosion system. Therefore, only in the dry wear tests previously performed [16] under the same tribological conditions (load, sliding speed and duration) big differences between the austenitic and martensitic stainless steels wear behavior were observed (the martensitic materials showed more than four times higher wear volumes than the austenitic one). These differences between the wear behavior of the same tested materials in dry and wet conditions have been also observed by Espallargas and Mischler [40]. Those authors studied the dry wear and tribocorrosion mechanisms of pulsed plasma nitride $\mathrm{Ni}-\mathrm{Cr}$ alloy using a reciprocating sliding tribometer with an alumnina ball as a counterpart. The maximum Hertzian pressure was around $1800 \mathrm{MPa}$ and they used $0.5 \mathrm{M} \mathrm{H}_{2} \mathrm{SO}_{4}$ as electrolyte when carrying on tribocorrosion tests. From their study, the dry wear results showed a much severe wear of the un-treated alloy than the plasma nitrided one, while in the lubricated tests no differences among the studied materials could be observed.

Because the wear coefficients of those dry tests were in the same range as the wet ones, it was suggested that the same nanowear mechanism was taking place. Akagaki and Kato [41] described this behavior as "filmy wear mechanism" in tribosystems under low friction (lubricated), and it was also reported by other authors [39][37]. Kapoor and Johnson [38] proposed a kinematically mechanism of extrusion in which a thin layer is uniformly compressed by shearing on the interface between the layer and the bulk of the soft asperity, based on the shakedown theorem of the theory of plasticity. These asperities are progressively extruded out in the form of thin slivers which subsequently break off to provide wear debris. Considering this approach, Figure 11 shows the wear coefficients $(K)$ of the stainless steels tested in dry [16] and wet conditions and those corresponding to the treated and untreated $\mathrm{Ni}$ $\mathrm{Cr}$ alloy from [40] as a function of the coefficient of friction $(\mu)$. The figure shows a threshold in the coefficient of friction suggesting a transition in wear mechanism when the coefficient of friction lies around 0.6. Below this threshold wear is independent on friction, material and environment, probably by nanowear or filmy wear mechanism, in which a nano-crystalline tribolayer is formed at the sliding surface through recrystallization of highly deformed metal grains. This tribolayer, which properties are different from the bulk material, develops on the martensitic and austenitic stainless steels and yields the same wear rate and morphology. However, above the coefficient of friction of 0.6 , the breakdown of the material below the nanocrystalline 
tribolayer is taking place and thus higher wear rates together with a high coefficient were found.

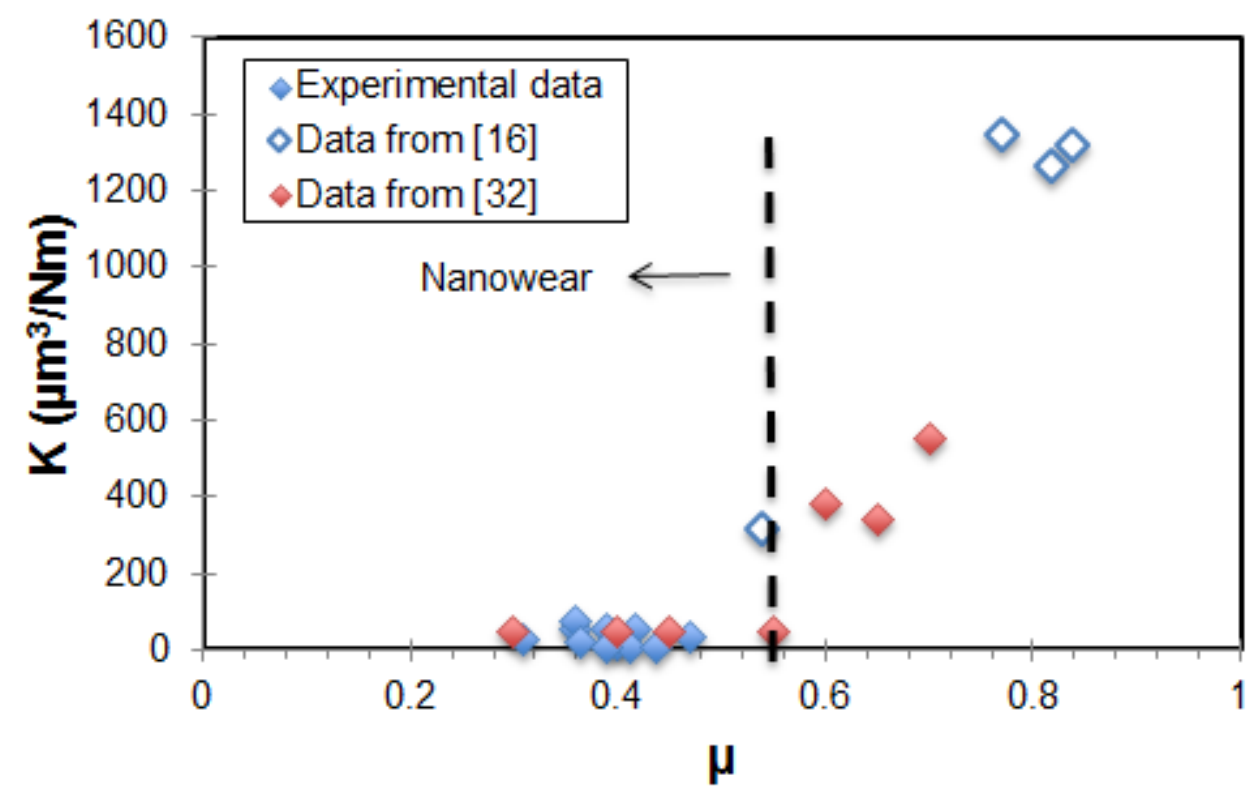

Figure 14. Wear coefficient $(K)$ versus the coefficient of friction $(\mu)$ of the wear tests in dry and wet conditions (experimental data) and of the results from [16] and [40].

\section{Conclusions}

The following conclusions can be drawn from the study of the tribocorrosion behaviour of new martensitic stainless steels in a $3 \% \mathrm{wt} \mathrm{NaCl}$ solution:

- Hardening takes place in the studied stainless steels while carrying out the tribocorrosion tests. Wear rates increased with the hardness ratio $\left(\mathrm{H}_{\text {in }} / \mathrm{H}_{\text {out }}\right)$ between 1.1. and 1.25, according to existing low-cycle fatigue and ratcheting models.

- The mechanical response of the studied stainless steels under tribocorrosion conditions is influenced by the electrochemical conditions: both mechanical wear and wear accelerated corrosion increase with the applied potential.

- Delamination is the main wear mechanism that takes place under tribocorrosion conditions in the studied stainless steels. The accumulated strain by sliding during tribocorrosion tests leads with shakedown and lowclycle fatigue wear mechanisms.

- Coefficients of friction below 0.6 promote nanowear and higher wear rates are reached when the coefficient of friction increases. 


\section{Acknowledgements}

The authors would like to thank to BPI, Region Centre and Tours Plus for support of this research. This work is done under the project FUI 11 Mekinox.

\section{References}

[1] H.K.D.H. Bhadeshia, Steels for bearings, Prog. Mater. Sci. 57 (2012) 268-435. doi:http://dx.doi.org/10.1016/j.pmatsci.2011.06.002.

[2] D.H. Mesa, A. Toro, A. Sinatora, A.P. Tschiptschin, The effect of testing temperature on corrosion-erosion resistance of martensitic stainless steels, Wear. $255 \quad$ (2003) 139-145. doi:http://dx.doi.org/10.1016/S00431648(03)00096-6.

[3] S. Mischler, A. Spiegel, D. Landolt, The role of passive oxide films on the degradation of steel in tribocorrosion systems, Wear. 225-229, P (1999) 10781087. doi:http://dx.doi.org/10.1016/S0043-1648(99)00056-3.

[4] Y. Xi, D. Liu, D. Han, Improvement of corrosion and wear resistances of AISI 420 martensitic stainless steel using plasma nitriding at low temperature, Surf. $\begin{array}{llll}\text { Coatings } & \text { Technol. } & 202 & \text { (2008) }\end{array}$ doi:http://dx.doi.org/10.1016/j.surfcoat.2007.09.036.

[5] R. Puli, G.D. Janaki Ram, Wear and corrosion performance of AISI 410 martensitic stainless steel coatings produced using friction surfacing and manual metal arc welding, Surf. Coatings Technol. 209 (2012) 1-7. doi:http://dx.doi.org/10.1016/j.surfcoat.2012.06.075.

[6] I. García, D. Drees, J.P. Celis, Corrosion-wear of passivating materials in sliding contacts based on a concept of active wear track area, Wear. 249 (2001) 452-460. doi:http://dx.doi.org/10.1016/S0043-1648(01)00577-4.

[7] A.C. Vieira, L.A. Rocha, N. Papageorgiou, S. Mischler, Mechanical and electrochemical deterioration mechanisms in the tribocorrosion of $\mathrm{Al}$ alloys in $\mathrm{NaCl}$ and in NaNO3 solutions, Corros. Sci. 54 (2012) 26-35. doi:http://dx.doi.org/10.1016/j.corsci.2011.08.041.

[8] J. Perret, E. Boehm-Courjault, M. Cantoni, S. Mischler, A. Beaudouin, W. Chitty, et al., EBSD, SEM and FIB characterisation of subsurface deformation during tribocorrosion of stainless steel in sulphuric acid, Wear. 269 (2010) 383393. doi:http://dx.doi.org/10.1016/j.wear.2010.04.023.

[9] S. Mischler, Sliding Tribo-Corrosion of Passive Metals: Mechanisms and Modeling, in: B. Peter, C. Jean-Pierre, D. Dirk, F. Friedrich (Eds.), TriboCorrosion Res. Testing, Appl., ASTM international, 2013: pp. 1-18. doi:10.1520/STP1563-EB.

[10] S. Mischler, A.I. Muñoz, Wear of CoCrMo alloys used in metal-on-metal hip joints: A tribocorrosion appraisal, Wear. 297 (2013) 1081-1094. doi:http://dx.doi.org/10.1016/j.wear.2012.11.061.

[11] A. Stachowiak, W. Zwierzycki, Tribocorrosion modeling of stainless steel in a sliding pair of pin-on-plate type, Tribol. Int. 44 (2011) 1216-1224. 
doi:http://dx.doi.org/10.1016/j.triboint.2011.05.020.

[12] A. Dalmau, A; Rmili, W; Dion, E; Benoit, R; , Ruyter, A; Richard, C.; Igual Muñoz, Electrochemical and surface chemistry characterization of new martensitic stainless steels in sodium chloride solution, Corros. Sci. Under revi (n.d.).

[13] M. El May, T. Palin-Luc, N. Saintier, O. Devos, Effect of corrosion on the high cycle fatigue strength of martensitic stainless steel X12CrNiMoV12-3, Int. J. Fatigue. 47 (2013) 330-339. doi:http://dx.doi.org/10.1016/j.ijfatigue.2012.09.018.

[14] M. Esfandiari, H. Dong, The corrosion and corrosion-wear behaviour of plasma nitrided 17-4PH precipitation hardening stainless steel, Surf. Coatings Technol. 202 (2007) 466-478. doi:http://dx.doi.org/10.1016/j.surfcoat.2007.06.069.

[15] N. Lin, F. Xie, H. Yang, W. Tian, H. Wang, B. Tang, Assessments on friction and wear behaviors of P110 steel and chromizing coating sliding against two counterparts under dry and wet conditions, Appl. Surf. Sci. 258 (2012) 49604970. doi:http://dx.doi.org/10.1016/j.apsusc.2012.01.128.

[16] A. Dalmau, W. Rmili, D. Joly, C. Richard, A. Igual-Muñoz, Tribological Behavior of New Martensitic Stainless Steels Using Scratch and Dry Wear Test, Tribol. Lett. 56 (2014) 517-529. doi:10.1007/s11249-014-0429-6.

[17] ASTM A514 / A514M-14, Standard Specification for High-Yield-Strength, Quenched and Tempered Alloy Steel Plate, Suitable for Welding, ASTM International, West Conshohocken, PA, 2014, www.astm.org, (n.d.).

[18] V.G. Pina, A. Dalmau, F. Devesa, V. Amigó, A.I. Muñoz, Tribocorrosion behavior of beta titanium biomedical alloys in phosphate buffer saline solution, J. Mech. Behav. Biomed. Mater. (n.d.). doi:http://dx.doi.org/10.1016/j.jmbbm.2015.02.016.

[19] R. Priya, C. Mallika, U.K. Mudali, Wear and tribocorrosion behaviour of 304L SS, Zr-702, Zircaloy-4 and Ti-grade2, Wear. 310 (2014) 90-100. doi:http://dx.doi.org/10.1016/j.wear.2013.11.051.

[20] M. Stemp, S. Mischler, D. Landolt, The effect of mechanical and electrochemical parameters on the tribocorrosion rate of stainless steel in sulphuric acid, Wear. 255 (2003) 466-475. doi:http://dx.doi.org/10.1016/S00431648(03)00085-1.

[21] Y. Sun, E. Haruman, Effect of electrochemical potential on tribocorrosion behavior of low temperature plasma carburized $316 \mathrm{~L}$ stainless steel in 1\&\#xa0;M H2SO4 solution, Surf. Coatings Technol. 205 (2011) 4280-4290. doi:http://dx.doi.org/10.1016/j.surfcoat.2011.03.048.

[22] A.I. Muñoz, N. Espallargas, 5 - Tribocorrosion mechanisms in sliding contacts, in: D. Landolt, S. Mischler (Eds.), Tribocorrosion Passiv. Met. Coatings, Woodhead Publishing, 2011: pp. 118-152. doi:http://dx.doi.org/10.1533/9780857093738.1.118.

[23] S. Mischler, Triboelectrochemical techniques and interpretation methods in tribocorrosion: A comparative evaluation, Tribol. Int. 41 (2008) 573-583. doi:http://dx.doi.org/10.1016/j.triboint.2007.11.003. 
[24] N. Papageorgiou, S. Mischler, Electrochemical Simulation of the Current and Potential Response in Sliding Tribocorrosion, Tribol. Lett. 48 (2012) 271-283. doi:10.1007/s11249-012-0022-9.

[25] S. Guadalupe Maldonado, S. Mischler, M. Cantoni, W.-J. Chitty, C. Falcand, D. Hertz, Mechanical and chemical mechanisms in the tribocorrosion of a Stellite type alloy, Wear. 308 (2013) 213-221. doi:http://dx.doi.org/10.1016/j.wear.2013.04.007.

[26] V.G. Pina, A. Dalmau, F. Devesa, V. Amigó, A.I. Muñoz, Tribocorrosion behavior of beta titanium biomedical alloys in phosphate buffer saline solution, J. Mech. Behav. Biomed. Mater. 46 (2015) 59-68. doi:10.1016/j.jmbbm.2015.02.016.

[27] N. Espallargas, R. Johnsen, C. Torres, A.I. Muñoz, A new experimental technique for quantifying the galvanic coupling effects on stainless steel during tribocorrosion under equilibrium conditions, Wear. 307 (2013) 190-197. doi:http://dx.doi.org/10.1016/j.wear.2013.08.026.

[28] M.F. and P.S. and S. Mischler, Effect of the applied potential of the near surface microstructure of a $316 \mathrm{~L}$ steel submitted to tribocorrosion in sulfuric acid, J. Phys. D. Appl. Phys. 39 (2006) 3175. http://stacks.iop.org/0022$3727 / 39 / \mathrm{i}=15 / \mathrm{a}=$ S07.

[29] A. Bidiville, M. Favero, P. Stadelmann, S. Mischler, Effect of surface chemistry on the mechanical response of metals in sliding tribocorrosion systems, Wear. 263 (2007) 207-217. doi:http://dx.doi.org/10.1016/j.wear.2007.01.066.

[30] S. Guadalupe Maldonado, S. Mischler, M. Cantoni, W.-J. Chitty, C. Falcand, D. Hertz, Mechanical and chemical mechanisms in the tribocorrosion of a Stellite type alloy, Wear. 308 (2013) 213-221. doi:http://dx.doi.org/10.1016/j.wear.2013.04.007.

[31] H. Xu, K. Komvopoulos, Surface adhesion and hardening effects on elasticplastic deformation, shakedown and ratcheting behavior of half-spaces subjected to repeated sliding contact, Int. J. Solids Struct. 50 (2013) 876-886. doi:http://dx.doi.org/10.1016/j.ijsolstr.2012.10.009.

[32] C.B. von der Ohe, R. Johnsen, N. Espallargas, Multi-degradation behavior of austenitic and super duplex stainless steel - The effect of 4-point static and cyclic bending applied to a simulated seawater tribocorrosion system, Wear. 288 (2012) 39-53. doi:http://dx.doi.org/10.1016/j.wear.2012.02.016.

[33] S. Mischler, A. Spiegel, M. Stemp, D. Landolt, Influence of passivity on the tribocorrosion of carbon steel in aqueous solutions, Wear. 251 (2001) 12951307. doi:http://dx.doi.org/10.1016/S0043-1648(01)00754-2.

[34] S.C. Lim, M.F. Ashby, Overview no. 55 Wear-Mechanism maps, Acta Metall. 35 (1987) 1-24. doi:http://dx.doi.org/10.1016/0001-6160(87)90209-4.

[35] S. Curtze, V.-T. Kuokkala, Dependence of tensile deformation behavior of TWIP steels on stacking fault energy, temperature and strain rate, Acta Mater. 58 (2010) 5129-5141. doi:http://dx.doi.org/10.1016/j.actamat.2010.05.049.

[36] R. Chattopadhyay, Surface Wear: Analysis, Treatment, and Prevention, ASM International, Ohio, 2001. doi:10.1361/swat2011p001. 
[37] K.L. Johnson, Contact mechanics and the wear of metals, Wear. 190 (1995) 162-170. doi:http://dx.doi.org/10.1016/0043-1648(95)06665-9.

[38] A. Kapoor, K.L. Johnson, Plastic ratchetting as a mechanism of erosive wear, Wear. 186-187, P (1995) 86-91. doi:http://dx.doi.org/10.1016/00431648(95)07179-2.

[39] S. Fouvry, P. Kapsa, L. Vincent, An elastic-plastic shakedown analysis of fretting wear, Wear. 247 (2001) 41-54. doi:http://dx.doi.org/10.1016/S00431648(00)00508-1.

[40] N. Espallargas, S. Mischler, Dry wear and tribocorrosion mechanisms of pulsed plasma nitrided $\mathrm{Ni}-\mathrm{Cr}$ alloy, Wear. 270 (2011) 464-471. doi:http://dx.doi.org/10.1016/j.wear.2010.12.008.

[41] T. Akagaki, K. Kato, Plastic flow process of surface layers in flow wear under boundary lubricated conditions, Wear. 117 (1987) 179-196. doi:http://dx.doi.org/10.1016/0043-1648(87)90254-7. 